\title{
'You Better Move On': Determinants and Labor Market Outcomes of Graduate migration from Italy
}

\begin{abstract}
After the Euro-crisis, out-migration from Southern Europe revived, mostly fed by the highly skilled young. Nevertheless, little is known about these new migrants, particularly regarding the determinants and payoffs of their moves. This paper delves into the Italian case, drawing on a large representative sample of the 2011 graduation cohort. Multivariate analyses show that young people from upper class families, foreign citizens, graduates in scientific and internationally-oriented fields and best-performing students are more likely to migrate. Moreover, compared to the 'stayers', graduate migrants enjoy more favorable outcomes in terms of wages, unemployment risks, access to skilled employment, and career satisfaction.
\end{abstract}

\section{Introduction}

The European Union has put enormous effort into supporting the cross-country mobility of European citizens as part of a broader strategy aimed at a complete integration of markets across the continent (Favell 2014; Recchi 2015). In this respect, we can mention the reduction of legal barriers to labor mobility across member states, the generous funding of programs promoting the international mobility of students, the Bologna process and the other policy measures aimed at developing a common European framework for higher education qualifications. Young and tertiary-educated workers have always been regarded as a flagship target of free movement policies, as they are equipped with skills and attitudes that tend to make them more migration-prone, and because they are able to reap the benefits of labor mobility for a longer time. After the Euro-crisis broke out, youth mobility was even more fervently invoked in Brussels as a major tool to fight unemployment in the economically distressed areas of the Union, explicitly framing free movement as a safety valve for highly skilled workers (Reding, Rehn and Andor 2013). In fact, the skilled labor shortages in other European and extra-European economies create a structural incentive to migration for tertiary graduates from Southern Europe who, even before the crisis, were already experiencing a highly problematic transition into the labor markets of their home countries (Barbagli 1982; Gangl 2001; BrzinskyFay 2007; Wolbers 2007).

Despite its policy relevance, there is remarkably little empirical research on the extent of and the economic returns to skilled migration from Southern Europe. More precisely, while several studies have assessed the occupational prospects of specific categories of skilled workers, such as researchers, scientists or engineers (De Grip et al. 2010), there is scant evidence about the overall population of graduates that would allow for a systematic comparison of the causes and consequences of high-skilled migration across different social profiles and across different destination countries. This research gap is most likely due to data constraints, since this more systematic analysis demands sizable and representative samples of graduates to be followed even when they migrate to a broad range of countries. This article is intended to fill this void, thanks to a high-quality data source that meets these standards for a recent, large, representative sample of Italian university graduates. In particular, we will first assess the overall propensity to migrate and its main determinants, and then proceed to estimating economic returns to migration for Italian graduates. We regard Italy as an ideal test case, since graduates in this country benefit from particularly low returns to education as compared to other OECD economies and, at the same time, they enjoy - thanks to the EU free 
movement regime - facilitated access to the labor markets of some European countries that face significant shortages of skilled human capital, such as Switzerland, Austria and Germany (Boeri et al. 2012). In addition, the employment outlook of the country has deteriorated after the economic crisis more than in other European countries. This may have intensified the propensity to migrate of Italian graduates.

In the next section, we will discuss our theoretical framework and hypotheses concerning the structural and institutional factors promoting skilled migration and its economic profitability in the Italian context. In section 3, we will present our data source, variables and methods. Section 4.1 contains evidence on the extent and determinants of migration, while section 4.2 assesses returns to migration for Italian graduates across five occupational outcomes (unemployment risks, earnings, access to highly skilled employment, self-perceived overeducation, career satisfaction). Section 5 outlines our concluding remarks.

\section{Framing high-skilled youth migration}

The neoclassical economic theory of migration represents a parsimonious explanation for international labor mobility (Arango 2000). This theoretical approach views the process of migration as an investment decision, where the returns to migration in terms of employment opportunities and higher wages should exceed the costs involved in moving. Following this theory, lifetime economic returns to migration should be higher for young, tertiary graduates, who are expected to display an above-average propensity to migrate, which is indeed the case in Western European countries (Fouarge and Ester 2008; Kahanec and Fabo 2013; Recchi and Salamońska 2015).

At the same time, sociologists have highlighted the role of non-economic drivers for cross-national resettlements. Educated youth in particular have been frequently shown to migrate for expressive reasons in the European context. For instance, Favell's (2008) portrait of 'Eurostars' is revealing of the complexities of such choices: tertiary-educated, young adults in three Western European capitals (London, Amsterdam and Bruxelles) who mostly migrated in search of a full-fledged recognition of their talent hardly fit into the stylized template of high-earning seekers in an international market. Other case studies resonate with similar accents in different geographical areas (Scott 2006; Krings et al. 2013; King et al. 2016), or as regards specific nationalities (Koikkalainen 2013). A survey-based study of Western intra-EU migrants found that, on balance, the affective dimension was at the root of a significant number of moves, reflecting an aspiration to reside with a partner of another nationality or to live one's sexuality outside the social control of the home environment (Santacreu et al. 2009). The key message of this literature is that enhanced spatial mobility reveals a mounting cosmopolitan lifestyle which expresses itself particularly in large cities (Beck 2008), thus feeding into an over-representation of highly-skilled youth among international migrants (Docquier and Machado Carneiro 2014).

It should be acknowledged that economic and expressive motives of migration intertwine or, as Massey (1990; 2003) aptly summarized, 'cumulate'. As regards the economic motives, the Italian labor market provides strong economic incentives to international migration for tertiary graduates. The demand for skilled workers is low in the Italian economy, due to the prevalence of small firms operating in traditional sectors (e.g., manufacturing, constructions, catering and tourism). Moreover, investments in R\&D are comparatively scarce, and occupation in the public sector, which was a major employer of Italian graduates in the past, has declined over the past two decades (Anvur 2014). Access to the liberal professions is constrained by the high degree of entry regulations (Patterson 2008). Unsurprisingly, in Italy, the employment share of professional and managerial jobs has stagnated over the past three decades (Ballarino et al. 2016). These structural problems have been further exacerbated by the economic recession that started in the late 2000s, which hit Italy severely. The cohort of university graduates that we consider 
in this work completed their studies in 2011 and have took their first steps in the labor market during this period of enhanced economic hardship.

The number of Italian graduates has considerably increased over the past three decades, spanning from 74,471 to 304,608 between 1987 and 2014 (Miur 2016). This growth has been primarily fed by a marked long-term growth of upper secondary graduation rates in the 1980s and 1990s, which swelled the student population eligible to enroll in Higher Education; the recent increase in the matriculation rate to university that has followed the so-called Bologna process, implemented on a national scale in 2001, has also contributed to the expansion of university enrollments ${ }^{1}$.

These structural unbalances between supply and demand of skilled employment shed light on a seeming paradox. The share of graduates is comparatively low in Italy (24\% of the $25-34$ years-old as opposed to an OECD average of $41 \%$ in 2014), but economic returns to tertiary degrees are equally low (OECD 2015). Despite the modest proportion of graduates in Italy, their unemployment rate in 2015 was at $16 \%$ among individuals aged 25-34, just as high as the corresponding value for upper secondary graduates $(16.3 \%)^{2}$. Moreover, the earnings premium of tertiary degrees is among the smallest in OECD countries (OECD 2015). This paradox is easily explained once we consider that the poor number of graduates in Italy also reflects the scarce demand for graduates in the labor market (Sestito 2014). Because employment opportunities and wage differentials are much more favorable for graduates in most other OECD countries, we can expect that international migration yields substantial economic returns for Italian graduates. We will test this first hypothesis by comparing Italian graduates who migrate abroad (movers) with Italian graduates who stay in the country (stayers) across five indicators of occupational performance:

H1: Ceteris paribus, movers display a smoother labor market transition than stayers as regards: a) unemployment risks; $b$ ) access to skilled employment; c) earnings; d) overeducation; e) career satisfaction.

Hence, we argue that Italian graduates have strong economic incentives to migrate. However, the choice to migrate also carries with it a number of significant economic and non-economic constraints. The recognition of educational qualifications is still far from being even across member states: the EU legislation is often translated partially or 'contextualized strategically' at the country level in order to protect insiders over external potential competitors (Paul 2013; Shaw and Miller 2013), and the situation can be even worse for graduates who migrate outside Europe; the difficult acknowledgement of past pension rights for movers is another well-known critical issue. Moreover, transaction costs associated with access to housing and paperwork needed for migration must be taken into account as costs of international resettlement. Additionally, language barriers play a critical role, especially in a multilingual mosaic like the EU (Adsera and Pytlikova 2015; Aparicio Fenoll and Kuehn 2014). This constraint is particularly important in Italy, where proficiency in foreign languages is comparatively weak (Eurobarometer 2012). Finally, the social and psychological costs of migration must be factored in, even though they are mitigated by cheaper and expanding means of transportation and communication in Europe over the last decades. These costs may

1 In more recent years, matriculations have started to decline, possibly due to the growing disillusion concerning the occupational prospects of the new bachelor degrees that have replaced the old 4- or 5-year degrees.

2 These data are available in the online data archive of Italian National Bureau of Statistics: dati.istat.it (consulted on March 2, 2016). 
be particularly high in a familistic society like Italy, where cultural norms converge with welfare state arrangements in promoting a long period of cohabitation of young adults with their parents, even after graduation and labor market entry, thus relying on informal exchanges between generations (Impicciatore 2015).

The above barriers to migration are not equally distributed among graduates, thus generating different propensities to migrate and different opportunities to reap the occupational benefits of migration. First, like in other countries, in Italy a more privileged social background is associated with higher foreign language proficiency, as well as with the development of more cosmopolitan attitudes and lifestyles that mitigate the social and psychological costs of migration (Gerhards 2014). Moreover, for upper class families, migration can represent a credentialing strategy associated with the attainment of prestigious foreign qualifications. Finally, these families can bear the economic costs of migration more easily. Second, foreign students who graduated in Italy are more likely to display cosmopolitan attitudes and to face lower social costs of migration back home; indeed, if they return to their country of origin, they can fall back on pre-existing networks of social support ${ }^{3}$. Moreover, considering the imbalance between supply and demand for skilled labor in Italy and the better economic prospects for graduates in several neighboring European countries, these foreign students have low incentives to stay in the country after graduation, rather choosing to invest their educational qualifications in more knowledge-intensive graduate markets. We would thus expect that:

H2: Ceteris paribus, the propensity to migrate is higher for: a) graduates from upper class families; $b$ ) graduates from foreign countries.

Moreover, fields of study differ in the marketability of their degrees and of the underlying skills. In some fields, human capital is highly nation-specific: this is particularly the case for law and for fields that cater specifically to national civil servants, such as social work. Inversely, degrees involving highly transferable skills, such as scientific fields, are more likely to promote migration; among fields displaying a high degree of skill transferability, those characterized by an explicit international orientation, such as foreign language and international relations, are more likely to recruit students with a cosmopolitan orientation and to develop foreign language skills that boost their inclination to migrate. Indeed, students in these fields can be channeled directly into foreign employment by their university institutions. Similarly, graduates from any field who took part in international exchange programs during their studies should be more likely to migrate because they developed skills and cultural attitudes which promote migration, and because these experiences abroad can reduce the information barriers which affect the transaction costs associated with migration. This leads us to formulate the following hypotheses:

H3: Ceteris paribus, the propensity to migrate is higher for: a) graduates of scientific and internationallyoriented fields; b) graduates who enrolled in international exchange programs during their university studies.

${ }^{3}$ The Italian system of Higher Education attracts few foreign students, who amount to $1.3 \%$ of the total of graduates. They are predominantly from Eastern Europe (55\%), Southern Europe (5.1\%) and Western continental Europe (7.7\%), while only few students come from Northern Europe $(0.3 \%)$ or from other Western countries (0.9\%). Citizens of developing countries amount to $31 \%$, with a similar share of students from South America, Africa and Asia. 
In the next section we present the data and the statistical methods that we have used to assess these hypotheses.

\section{Data and methods}

We tested the above hypotheses using data from a large-scale survey on Italian tertiary graduates' careers (Indagine sull'inserimento professionale dei laureati), conducted by the Italian National Bureau of Statistics (ISTAT) in 2015. ${ }^{4}$ This survey involves a representative sample of 58,400 individuals who obtained a tertiary degree in 2011 (26,741 individuals completed a Bachelor programme, BA hereafter, and 31,659 completed a Master programme, MA). These data provide detailed information on the educational and labor market outcomes of graduates, together with information concerning their country of residence at the time of the interview.

ISTAT follows graduates regardless of their country of residence, and the documentation of this survey does not report higher attrition rates for movers. We have data on 2,857 graduates who lived abroad at the time of the interview - that is, four years after graduation. We have grouped their destination countries in the following six categories: Northern Europe (Scandinavia, United Kingdom and Ireland), Western Continental Europe (including France), Southern Europe, Eastern Europe, economically developed countries outside Europe (mostly the United States, Canada and Australia), and a residual category that includes developing countries. The motivation behind this classification is to maximize the level of detail of the analyses, taking into account the low numbers for extra-European countries. For the same reason, we will differentiate by country of destination only in the analyses on occupational returns to migration, and not in those concerning the determinants of migration.

Unfortunately, our cross-sectional data do not provide information on the timing of foreign migration, which is a significant limitation. Our picture is a snapshot of migration at a given time and therefore excludes people who may have migrated in previous years and returned. However, since the sample comprises individuals who graduated from an Italian university, we can reasonably assume that migration took place after graduation for most of them. BA-holders who, after graduating in 2011, subsequently obtained a MA degree are excluded from the analytical sample. Indeed, these individuals are not comparable with the other BA graduates because of their different educational trajectory (three vs. five years of tertiary education), nor with MA graduates, due to different work experience ${ }^{5}$. We thus end up with an analytical sample of 47,534 individuals. Graduates who were still studying in 2015 are included in the first part of the analyses, which refers to the social determinants of migration, but not in the analyses

$4 \quad$ ISTAT adopted a two-stage process of data collection. In the first stage, all Italian universities were asked to provide administrative information and contact data for all their graduates of the 2011 cohort. From this complete list of the population, which referred to 299,449 graduates, the sample of graduates to be interviewed was drawn. In the second stage, the questionnaires were administered by means of a mixed CATI/CAWI method. ISTAT adopts state-of-the-art procedures to maximize randomness and representativeness of the samples, and its official status favours higher response rates than most private research institutes. Nevertheless, the response rate is $70.2 \%$, while we are not in a position to assess the non-response risk of different categories of potential respondents.

5 Since we do not know whether these graduates have achieved their master degree in Italy or abroad, it is difficult to include them in the analyses. 
on the occupational careers of graduates. For this second part of the analyses, the analytical sample thus includes 41,301 graduates.

Three sets of analyses are presented in the next section. First, the determinants of migration are assessed by means of logistic regression models, where the dependent variable is a dummy which equals to 1 if the graduate was living abroad four years after graduation, and 0 otherwise. These models include sociodemographic factors (sex, age, parents' occupational class $^{6}$, citizenship), information on the educational careers of respondents (type of upper secondary diploma, academic performance in upper secondary education, university matriculation year, type of tertiary degree, field of study, public or private university, final graduation mark in university), as well as information related to mobility experiences before graduation (country or geographic area of residence before enrolling at university, geographic area of the university, and study abroad experiences during university education).

As regards the analyses of the occupational outcomes of migration, we will first estimate a multinomial logit model, where the dependent variable is employment condition, measured in four categories: employed, unemployed, student, other condition of inactivity. This model includes, alongside the control variables listed above, a variable for the country of residence of graduates at the time of the interview ${ }^{7}$.

Then, conditional on being employed, we will consider four occupational outcomes: net monthly earnings, access to highly skilled employment, and two subjective indicators concerning perceived overeducation and satisfaction for career prospects. As regards earnings, we control for cross-national differences in the cost of living by adjusting graduates' earnings by the Purchasing Power Parity conversion factor for 2015, as reported by the World Bank; the results for this adjustment are presented in the descriptive table below. As can be seen, adjusting by purchasing power results in substantial corrections of cross-country differentials in the earning prospects of Italian graduates.

\section{[TABLE 1 ABOUT HERE]}

Moreover, in order to control for different working-time regimes across countries, monthly earnings have been converted into hourly earnings. We take the logarithm of net hourly earnings as dependent variable. Access to highly skilled employment is a dummy variable that is equal to 1 if the individual is employed in an occupational category within the ISCO 1997 major groups 1 (Managers) or 2 (Professionals), 0 otherwise. Perceived overeducation is defined by respondents' self-assessment of the match between their level of education and the educational requirements of their jobs ("Was a tertiary degree necessary to get your current job?"; overeducation occurs whenever respondents answer "No"). Finally, graduates were surveyed about their level of satisfaction with regard to the career prospects of their current job (very satisfied, fairly satisfied, a little satisfied, not at all satisfied); the variable takes value 1 if the individual is very satisfied, 0

6 A dominance criterion is adopted to construct this variable: parents' occupational class is defined by the highest level observed among the parents.

7 It can be objected that the choice of a destination country is not exogenous to the occupational situation. We have therefore run the models with a simple dummy for movers/stayers. The substantive conclusions are unchanged. 
otherwise ${ }^{8}$. The functional form of regression models for the above outcomes depends on the nature of the dependent variables: it is linear for earnings and logistic for the remaining outcomes. The set of control variables is the same as for occupational status, plus a dummy for part-time employment, a dummy that indicates whether the graduate worked during university and a dummy that marks whether the job at the time of the interview started after graduation.

Despite this rich set of controls, it is of course possible that the models omit some significant predictors of occupational attainment that are not equally distributed among movers and stayers. For instance, we cannot control neither for achievement orientations, nor for standardized measures of cognitive ability. Therefore, due to this selection issue, we cannot interpret our coefficients in causal terms ${ }^{9}$. However, we will see in the next section that movers are only a moderately selected population in terms of characteristics that are known to correlate with achievement orientations and ability, such as measures of academic performance. Moreover, in order to strengthen the robustness of our analyses, we will compare the standard regression-based estimates with propensity score matching estimates. Propensity score matching aims at mimicking experimental treatment randomization in the context of observational settings, and it ensures that regression-based estimates are not undermined by a lack of common support (Kaliendo and Kopeinig 2005). The idea is to create a sample of units that received the treatment (in our case, people who migrated) which is comparable to a sample of units that did not receive it on all observed covariates. The propensity score is defined as the probability of being exposed to the treatment $(D=1)$ conditioning on a set of observable characteristics $X$. Formally:

$$
p(X)=P\{D=1 \mid X\}
$$

In our case, $\mathrm{D}$ is a dummy equal to 1 if the individual migrated, 0 otherwise, and the propensity score is computed on the set of covariates listed above, which account for socio-demographic factors, educational career indicators, and previous experiences of mobility. Then, treated individuals (movers) are matched with non-treated individuals (stayers) and their occupational outcomes are compared in order to have an ATT estimate (average treatment effect on the treated) of the "effect" of migration ${ }^{10}$.

\section{Results}

\subsection{The extent and determinants of migration}

In this section we will first describe the extent of international migration of Italian graduates and the profile of movers, and then assess the occupational outcomes of movers. Table 2 reports that $4.7 \%$ of tertiary graduates live abroad four years after graduation; in absolute terms, this means that every year almost 14,000 Italian graduates migrate abroad. This figure is consistent with the results reported by Becker et al. (2004), who estimated that, in the late 1990s, between $3 \%$ and $5 \%$ of Italian college graduates were

8 Additional analyses have been conducted where the dependent variable is equal to 1 if the interviewees answer "a lot" or "quite a lot", 0 otherwise. The results are virtually identical to those reported in the article (available upon request).

${ }^{9}$ Unfortunately, the dataset does not contain any variable that could be used as a plausible instrument to account for selection into migration.

10 More specifically, we use caliper matching, where each treated $i$ is matched to the closest nontreated $j$ in terms of the propensity score, within a predefined radius that we set at 0.01 . 
dispersed abroad in the year after graduation ${ }^{11}$. In 2007, another large sample study found that five years after graduation $3 \%$ of Italian graduates lived abroad (Almalaurea 2008) ${ }^{12}$. Recent studies suggest that these figures may in fact have increased quite steeply after 2011 (Rosina 2014; Anelli and Peri 2016). Indeed, if we consider the previous wave of our survey, carried out in 2011 on individuals who graduated in 2007 , the migration rate is significantly lower (2.4\%).

Unsurprisingly, the majority of migrants opt for a European country, in line with theoretical arguments and empirical research, which indicate that the economic and extra-economic costs of migration are a key determinant of the choice of destination country. Indeed, the neighboring graduate markets of Western continental Europe that display a sustained demand for tertiary graduates (mainly Germany, Switzerland, and France) are the preferred destinations of Italian graduates: they absorb four migrants out of ten. UK, Ireland and Scandinavia hold lower but significant attraction, while other European countries, as well as extra-European destinations, host a limited portion of graduates.

\section{[TABLE 2 ABOUT HERE]}

Table 3 presents the results concerning the determinants of migration. The influence of the covariates is described by the average marginal effects, which refer to changes in the probability to migrate. The first model incorporates only socio-demographic predictors, while the second model also includes information on educational careers and previous mobility experiences. As can be seen, women and older respondents display lower propensities to migrate, as is also found in research on migration intentions (Recchi and Salamońska 2015, 136-7). Possibly, they are more likely to experience constraints to mobility stemming from family or personal relationships. Supporting hypotheses $2 a$ and $2 b$, international migration is less common among working class graduates (-2.7 percentage points, and -2.3 if the head of the household is not employed) and more common among foreign students who graduated in Italy ( +6.4 percentage points).

\section{[TABLE 3 ABOUT HERE]}

Model 2 indicates that academic performance in upper secondary and in tertiary education is positively associated with the propensity to migrate: better-performing students are more likely to move on. Moreover, in line with hypotheses $3 a$ and $3 b$, the propensity to migrate is higher among graduates from fields of study that provide students with more easily transferable skills, such as foreign language (+3.6 percentage points) and scientific fields ( +3.3 percentage points), and among students that have participated in international exchange programs $(+5.7 \text { percentage points })^{13}$. The results discussed so far

11 This estimate is based on a 5\% random sample of the official register of Italians residing abroad. Unfortunately, this register is notoriously problematic as regards education, and the authors themselves note that $30 \%$ of their cases are missing for this variable.

12 Another study of Italian PhD holders three to five years after the discussion of their dissertation reported that $6.4 \%$ of them lived abroad. Of course, this higher rate refers to a specific sub-population of graduates that is, by the very nature of scientific work, embedded in international networks and epistemic communities (ISTAT 2011).

13 Model 2 also reveals that universities in Northern Italy are significantly more likely to yield graduate out-migration flows. This may reflect their overall higher academic status and thus the marketability of their degrees internationally. Northern Italian universities tend to drain high performing students from the 
move in the expected direction and confirm previous research which outlines that international migrants tend to be a positively selected population (Belot and Hatton 2012).

Finally, a previous experience of migration is a powerful determinant of the propensity to move after graduation. Respondents who lived abroad before enrolling at university are more likely to migrate than residents in Italy; this effect is particularly strong (+67.7 percentage points). Of course, it is unsurprising that foreign students who graduated in Italy display a higher inclination to leave the country after graduation, since they face lower transaction costs, particularly if they return to their home countries. Moreover, these students are likely to be positively selected in terms of attitudes associated with a higher propensity to migrate which may lead them to reap the benefits of their educational investments in labor markets that offer better occupational prospects than Italy. Due to data constraints, we are not able to discriminate between these two hypotheses. What this result clearly indicates is the inability of the Italian system to absorb (and benefit from) the skilled foreign workers that it has contributed to train.

\subsection{The occupational outcomes of movers}

In Table 4 we present the results of a multinomial logit model for the probability of being a student, employed or unemployed, as opposed to being inactive (reference category). To save space, the table reports only the coefficients of interest (the full results are reported in the appendix).

\section{[TABLE 4 ABOUT HERE]}

Movers are much more often students, except those living in Eastern Europe and in developing countries. Conversely, they are less often employed, while differentials in unemployment risks are small and never statistically significant. Hypothesis $1 a$ is thus not supported: at least in the years immediately after graduation, migration is markedly geared to further education and does not translate into higher employment rates. These results suggest that direct entry into the labor market is not necessarily the dominant motive of migration. Migrating to developed countries with a rich supply of internationally recognized universities may also reflect a broader credentialing strategy that can be appealing for graduates who plan to return to Italy after having completed their graduate studies abroad. It is also possible that the degrees of Italian graduates are not fully appreciated by employers in the destination countries and that they are therefore obliged to strive for additional qualifications.

We can now assess the occupational outcomes of those movers who do find employment abroad in comparison with stayers ${ }^{14}$. Table 5 presents two sets of estimates for each occupational outcome: standard regression-based estimates and propensity score matching estimates. As can be seen, propensity-score estimates confirm quite closely regression-based estimates. Both sets of estimates indicate that migration is definitively a rewarding investment for Italian graduates. First, the average net hourly salary of movers,

South, in a country where South-North internal migration has picked up again over the last decade (Panichella 2014).

${ }^{14}$ It is worth noting that we did not detect any relevant difference between migrants and stayers with respect to the main characteristics of jobs, namely type of contract and sector of employment. The only exception is that stayers are more frequently employed in the health sector, which is not surprising if we consider that graduates from the corresponding field are among the least inclined to move (see tab. 3) 
adjusted by purchasing power, is 36.2 percentage points higher than the salary of stayers ${ }^{15}$. Second, movers have more often access to highly skilled managerial and professional occupations: the differential amounts to almost 7 percentage points (the base probability is 50\%). Movers are also much more satisfied with the career opportunities offered by their jobs: the advantage over stayers is comprised between 19 and 20 percentage points (the base probability of being very satisfied is $32 \%)^{16}$.

\section{[TABLE 5 ABOUT HERE]}

However, movers are more dissatisfied than stayers when it comes to the perceived risks of overeducation, at least when looking at propensity-score estimates. We have just seen that an objective, ISCO-based measure of the skill level of occupations reveals a substantial gap in favor of movers, and that this gap translates into considerable earnings differentials. Indeed, we have argued that, given the characteristics of the Italian labor market, migration should substantially increase the chances to access highly skilled jobs. However, the subjective perceptions of movers and stayers do not reflect this gap. This is less surprising once we consider that the definition of 'graduate job' is subjective and possibly largely influenced by the characteristics of the broader context. Hence, graduates may downwardly adjust their expectations concerning graduate jobs in contexts - such as the Italian labor market - where the availability of these jobs is restricted. Conversely, it is also possible that movers left Italy with too high (or even unrealistic) expectations, and that this is reflected in their judgements.

We also estimated the above models with the inclusion of interaction terms between the dummy for migration and gender, social origin, or field of study. These analyses show no statistically significant difference, suggesting that the occupational gaps between movers and stayers do not differ between men and women, between fields of study, or social classes of origins (results available upon request). However, caution is needed when interpreting these results, since the lack of statistical significance may simply reflect a lack of statistical power.

Figure 1 plots the regression-based coefficients for the four selected occupational outcomes across the six clusters of destination countries, always taking stayers as reference category (the full results are reported in the Appendix). These coefficients clearly indicate that the occupational prospects of movers differ across destinations. Net of purchasing power, movers always earn more than stayers, but the gap is particularly strong for graduates who live in developing extra-European countries (the earnings premium relative to stayers is $+75.9 \%$ ); the earnings of graduates living in developed countries are $42.9 \%$ higher than the earnings of stayers. Graduates who remain within the European borders benefit from migration, although to a lower extent: compared to living in Italy, the earnings premium of migration is $+35.7 \%$ in Continental Europe, $+40.1 \%$ in Eastern Europe, $+27.7 \%$ in Northern Europe and $+16.1 \%$ in Southern Europe. We may

\footnotetext{
${ }^{15}$ As a robustness check, we have rerun these models using the previous wave of this survey, carried out in 2011. The patterns are highly similar, but we detect lower returns to migration. For instance, the earnings premium has risen from $27.2 \%$ in 2011 to $36.2 \%$ in 2015.

${ }^{16}$ These results are quite reassuring, if we consider the reasons behind migration. ISTAT survey does not include any specific question about the main motive of migration, but migrants are asked to rate the level of importance of a set of possible drivers of their choice. Job-related aspects - such as the possibility of finding a more qualified and highly rewarded job - systematically score higher than personal reasons or study opportunities. For a qualitative study of migration motives of young Italians, see Caneva (2016).
} 
thus conclude that the higher the economic and non-economic costs of migration are, as indicated by the choice of a destination country overseas, the higher its economic benefits. This is consistent with existing comparative evidence on the occupational attainments of migrants, which tend to rise the greater the distance from the country of origin (Spörlein and van Tubergen 2014).

\section{[FIGURE 1 ABOUT HERE]}

Moving to results concerning the other outcomes, access to highly skilled employment is more likely in all destination regions: the point estimates suggest that the gap is weaker in Southern and Northern Europe and particularly large in extra-European countries. In terms of perceived career opportunities (i.e., job satisfaction), movers are in an advantageous position everywhere, but less so in Southern Europe. Finally, in line with our previous remarks concerning the subjective bias of the indicator of overeducation, we see that perceived overeducation is found to be lower than in Italy only in developing countries. Overall, we may conclude that migration to developing nations is particularly rewarding and that migration towards the Southern European neighbors is the least rewarding option.

\section{Conclusions}

Our analyses indicate that international migration sets out a promising scenario for Italian graduates. Compared to their counterparts that enter the national labor market, movers benefit from higher chances of accessing highly skilled jobs with better career opportunities, and they enjoy an earning premium of $+36 \%$, adjusting for differences in purchasing power. This premium rises to $+42.9 \%$ if they move to developed extra-European nations (mainly the US, Canada and Australia) and even to $+75.1 \%$ if they settle in developing countries. Given the great labor market predicaments faced by graduates in Italy, we expected international migration to yield positive returns, but the magnitude of these differentials is quite sizable. To repeat, we cannot interpret these labor market differentials in causal terms, but their magnitude is so sizeable that it is difficult to claim that they are entirely due to selection effects.

Interestingly, movers do not enjoy any advantage when it comes to the perceived chances of access to graduate jobs. This is unsurprising, if we consider that the perception of what constitutes a graduate job is also shaped by the labor market context: in a country where graduates are frequently demoted to less skilled jobs, the notion of 'graduate job' is likely to be broadened. If this interpretation is correct, Italian graduates may fail to fully appreciate the occupational opportunities which open to them by choosing to migrate. More generally, it may be noted that if our results concerning the very high economic returns to migration enjoyed by Italian graduates are novel within the academic community, the general public may not be expected to be better informed.

In the light of these findings, the share of graduates who leave the country (4.7\%) may even look low. This seeming paradox is resolved if we consider the multiple barriers to international migration that we have discussed. We would like to especially highlight two hurdles that are prominent in the Italian case: on the one hand, the knowledge of foreign languages, which is remarkably weak among Italian students; on the other, the 'social costs' of migration, which are likely to be higher in a familistic society like Italy. Indeed, we have found that students in internationally-oriented fields and with international study experiences, as well as foreign students who graduated in Italy, display a significantly higher propensity to migrate after graduation. This suggests that, when language barriers and social costs of migration are lower, graduates are more ready to reap the economic benefits of crossing national borders.

If our interpretation is correct, the international mobility of graduates may be enhanced by removing information and language barriers. It should be clear, however, that this 'safety valve' cannot replace 
macroeconomic policies aimed at creating skilled employment opportunities for Italian youth. Our results suggest that an expansion of international migration may entail negative consequences not only in terms of brain drain, but also of social inequality. Upper class graduates are better equipped to expatriate both to strengthen their educational credentials and to improve their occupational prospects. Currently, the migration rate is quite low, so that this dynamic cannot play any major role. However, our analysis of the relative propensities to migrate suggests that, far from promoting an equalization of opportunities, the opening of a geographically larger labor market for high-skilled youth may work as an additional avenue of social reproduction. 


\section{References}

Adsera, A. and M. Pytlikova (2015). "The role of language in shaping international migration", in The Economic Journal, 125(586): F49-F81.

Anelli, M. and G. Peri (2016). "Does Emigration Delay Political Change? Evidence from Italy during the Great Recession", NBER Working Paper 22350. NBER : Cambridge (Ma).

Aparicio Fenoll, A. and Z. Kuehn. (2014). "Does foreign language proficiency foster migration of young individuals within the European Union?", No. 8250. Institute for the Study of Labor (IZA).

Arango, J. (2000). "Explaining migration: a critical view", International Social Science Journal, 52(165): 283296.

Balduzzi, P. and A. Rosina (2011). “Giovani talenti che lasciano l'Italia: fonti, dati e politiche di un fenomeno complesso", Rivista delle Politiche Sociali, 3: 43-60.

Barbagli, M. (1982). Educating for Unemployment: Politics, Labor Markets, and the School System--Italy, 1859-1973. New York: Columbia University Press.

Beck, U. (2008). "Mobility and the cosmopolitan perspective", in Weert, C., Kaufmann, V. and S. Kesselring (eds), Tracing mobilities: Towards a cosmopolitan perspective, Farnham: Ashgate, 25-35.

Becker, S. O., Ichino, A., and G. Peri (2004). "How Large is the" Brain Drain" from Italy?", Giornale degli Economisti e Annali di Economia: 1-32.

Belot, M. V. K. and Hatton, T. J. (2012). "Immigrant Selection in the OECD", in The Scandinavian Journal of Economics, 114: 1105-1128.

Boeri, T., Brücker, H., Docquier, F. and H. Rapoport (2012). Brain drain and brain gain: the global competition to attract high-skilled migrants, Oxford: Oxford University Press.

Brzinsky-Fay, C. (2007). "Lost in transition? Labour market entry sequences of school leavers in Europe", European Sociological Review, 23(4): 409-422.

Caliendo, M. and Kopeinig, S. (2005). Some practical guidance for the implementation of propensity score matching. IZA discussion series 1588.

Caneva, E. (2016). “Giovani italiani che emigrano: percorsi di vita inediti all'epoca della crisi economica globale", Mondi migranti, 10(3): 79-93.

De Grip, A., Fouarge, D. and J. Sauermann. (2010) "What affects international migration of European science and engineering graduates?", Economics of Innovation and New Technology, 19(5): 407-421.

Docquier, F. and Machado, J. (2014). "Global competition for attracting talents and the world economy" IRES Discussion Papers.

Eurobarometer (2012). "Europeans and their Languages," Special Eurobarometer 386, Directorate General for Education and Culture, European Commission.

Favell, A. (2008). Eurostars and Eurocities: Free Movement and Mobility in an Integrating Europe, Oxford: Blackwell.

Favell, A. (2014). Immigration, Integration and Mobility: New Agendas in Migration Studies. ECPR Press: Colchester. 
Fouarge, D., and P. Ester. (2008). "How willing are Europeans to migrate? A comparison of migration intentions in Western and Eastern Europe", in Ester P., Muffels R., Schippers J. and T. Wilthagen (eds) Innovating European Labour Markets. Dynamics and Perspectives, Edward Elgar: Cheltenham.

Gangl, M. (2001). "European patterns of labour market entry. A dichotomy of occupationalized vs. nonoccupationalized systems?", European Societies, 3(4): 471-494.

Gerhards, J. (2014). "Transnational linguistic capital: Explaining English proficiency in 27 European countries.", International Sociology, 29(1): 56-74.

Impicciatore, R. (2015). "The Transition to Adulthood of the Italian Second Generation in France", European Journal of Population, 31(5): 529-560.

Istat (2011). Mobilità interna e verso l'estero dei dottori di ricerca , in Focus, 27-12-2011.

Kahanec, M. (2013). "Labor mobility in an enlarged European Union", in International handbook on the economics of migration, 137-152.

Kahanec, M. and B. Fabo (2013). "Migration strategies of the Crisis-Stricken Youth in an Enlarged European Union", Transfer: European Review Of Labor and Research, 19(3): 365-380.

King, R. (2015). "Migration and Southern Europe. A Center-Periphery Dynamic?", in M. Baumeister and R. Sala (eds) Southern Europe?: Italy, Spain, Portugal, and Greece from the 1950s until the present day, Frankfurt am Main: Campus.

King, R., Lulle, A., Conti, F., and Mueller, D. (2016). "Eurocity London: a qualitative comparison of graduate migration from Germany, Italy and Latvia", Comparative Migration Studies, 4(1): 1-22.

Koikkalainen, S; (2013). Making It Abroad: Experiences of Highly Skilled Finns in the European Union Labour Markets, Rovaniemi: University of Lapland.

Krings, T., Bobek, A., Moriarty, E., Salamońska, J. and J. Wickham. (2013). “Polish Migration to Ireland:'Free Movers' in the New European Mobility Space", Journal of Ethnic and Migration Studies, 39: 87-103.

Massey, D.S. (1990). "Social structure, household strategies, and the cumulative causation of migration", Population index: 3-26.

OECD (2015). Education at a glance2015: OECD Indicators, OECD Publishing.

Panichella, N. (2014). Meridionali al Nord: migrazioni interne e società italiana dal dopoguerra ad oggi. Bologna: II Mulino.

Paul, R. (2013). 'Strategic Contextualisation: Free Movement, Labour Migration Policies and the Governance of Foreign Workers in Europe', Policy Studies, 34, 122-141.

Raftery, A.E., and M. Hout. (1993). "Maximally maintained inequality: Expansion, reform, and opportunity in Irish education, 1921-75.", Sociology of education: 41-62.

Recchi, E. (2015). Mobile Europe: The Theory and Practice of Free Movement in the EU, Basingstoke: Palgrave Macmillan.

Recchi, E. and J. Salamońska (2015). "Bad Times, Good Times to Move? The Changing Landscape of Intra-EU Migration", in Trenz, H.J., Ruzza, C. and V. Guiraudon (eds), Europe's Prolonged Crisis. The making or the Unmaking of a Political Union, Basingstoke: Palgrave Macmillan: 124-147. 
Reding, V., Rehn, O. and Andor, L. (2013). Labour Mobility: Europe's Chance to Battle the Crisis, http://ec.europa.eu/commission_2010-2014/andor/headlines/articles/2013/05/20130508_en.htm, May 8 (accessed May 21, 2013).

Rosina, A. (2014). http://www.neodemos.info/rassegnarsi-o-andarsene-la-fin-troppo-facile-scelta-deigiovani-italiani/

Santacreu O., Albert, M.C. and E. Baldoni (2009). "Deciding to move: migration projects in an integrating Europe", in Recchi, E. and A. Favell (eds.) Pioneers of European Integration: Citizenship and Mobility in the EU, Cheltenham: Edward Elgar.

Scott, S (2006). "The Social Morphology of Skilled Migration: The Case of the British Middle Class in Paris", Journal of Ethnic and Migration Studies, 32(7): 1105-1129.

Shaw, J. and Miller, N. (2013). "When legal worlds collide: An exploration of what happens when EU free movement law meets UK immigration law", European Law Review, 2: 137-166.

Spörlein, C. and van Tubergen, F. (2014). "The occupational status of immigrants in Western and nonWestern societies", International Journal of Comparative Sociology, 55(2): 119-143.

Wolbers, M. H. (2007). "Patterns of labour market entry. A comparative perspective on school-to-work transitions in 11 European Countries", Acta Sociologica, 50(3), 189-210. 
Table 1 Average net monthly earnings with and without adjustment for the PPP conversion factor, by area of residence. 2015

\begin{tabular}{lcc}
\hline \multicolumn{2}{c}{ Average net monthly earnings } & $\begin{array}{c}\text { Average net monthly earnings adjusted for } \\
\text { the PPP conversion factor }\end{array}$ \\
\hline Italy & 1,307 & 1,743 \\
Northern Europe & 2,289 & 2,414 \\
Western Continental Europe & 2,419 & 2,723 \\
Southern Europe & 1,376 & 2,027 \\
Eastern Europe & 1,351 & 3,310 \\
Developed extra-EU countries & 2,499 & 2,692 \\
Developing extra-EU countries & 2,400 & 7,645 \\
\hline
\end{tabular}

Source: own elaboration on ISTAT data (2015)

Table 2 Distribution of graduates across countries. 2015

\begin{tabular}{lrr}
\hline & $\mathbf{N}$ & $\mathbf{\%}$ \\
\hline Italy & 45,297 & 95.3 \\
Abroad & 2,237 & 4.7 \\
$\quad$ Northern Europe & 625 & 1.3 \\
Western Continental Europe & 939 & 1.9 \\
Southern Europe & 175 & 0.4 \\
Eastern Europe & 85 & 0.2 \\
$\quad$ Developed extra-EU countries & 218 & 0.5 \\
$\quad$ Developing extra-EU countries & 195 & 0.4 \\
\hline Total & 47,534 & 100.0 \\
\hline
\end{tabular}

Source: own elaboration on ISTAT data (2015) 
Table 3 Determinants of migration. Logistic regression models, average marginal effects. 2015

\begin{tabular}{|c|c|c|c|}
\hline & & Mod. 1 & Mod. 2 \\
\hline \multirow[t]{2}{*}{ Sex (Male) } & Female & $-0.016^{* * *}$ & $-0.014 * * *$ \\
\hline & & $(0.002)$ & $(0.002)$ \\
\hline \multirow[t]{4}{*}{ Age (Less than 25) } & $25-29$ & -0.003 & $-0.012 * * *$ \\
\hline & & $(0.002)$ & $(0.003)$ \\
\hline & $30+$ & $-0.034 * * *$ & $-0.023 * * *$ \\
\hline & & $(0.003)$ & $(0.004)$ \\
\hline \multirow[t]{12}{*}{ Parents' occupational class (Manager/professional) } & Entrepreneur & $-0.020 * * *$ & -0.011 \\
\hline & & $(0.008)$ & $(0.008)$ \\
\hline & Clerk & $-0.015^{* * *}$ & $-0.007^{* * *}$ \\
\hline & & $(0.002)$ & $(0.002)$ \\
\hline & Self-employed & $-0.009 *$ & -0.001 \\
\hline & & $(0.005)$ & $(0.005)$ \\
\hline & Manual worker & $-0.027^{* * *}$ & $-0.013^{* * *}$ \\
\hline & & $(0.003)$ & $(0.003)$ \\
\hline & Unemployed/Inactive & $-0.023 * * *$ & $-0.010 * * *$ \\
\hline & & $(0.003)$ & $(0.003)$ \\
\hline & Unknown & 0.014 & 0.020 \\
\hline & & $(0.022)$ & $(0.022)$ \\
\hline \multirow[t]{2}{*}{ Citizenship (Italian) } & Foreign & $0.064 * * *$ & $0.043 * * *$ \\
\hline & & $(0.008)$ & $(0.008)$ \\
\hline \multirow[t]{4}{*}{ Residence before university (region of university) } & Other region & $0.015 * * *$ & $0.008^{*}$ \\
\hline & & $(0.002)$ & $(0.002)$ \\
\hline & Abroad & $0.677^{* * *}$ & $0.554 * * *$ \\
\hline & & $(0.025)$ & $(0.029)$ \\
\hline \multirow{10}{*}{ Type of secondary degree (Scientific lyceum) } & Classical lyceum & & 0.000 \\
\hline & & & $(0.003)$ \\
\hline & Foreign-language lyceum & & $-0.011 * * *$ \\
\hline & & & $(0.004)$ \\
\hline & Other lyceum & & $-0.013^{* * *}$ \\
\hline & & & $(0.003)$ \\
\hline & Technical school & & $-0.016 * * *$ \\
\hline & & & $(0.003)$ \\
\hline & Vocational school & & $-0.020 * * *$ \\
\hline & & & $(0.005)$ \\
\hline \multirow[t]{2}{*}{ Upper secondary graduation mark } & & & $0.032 * * *$ \\
\hline & & & $(0.006)$ \\
\hline \multirow[t]{2}{*}{ Matriculation year } & & & $-0.001 * * *$ \\
\hline & & & $(0.001)$ \\
\hline \multirow[t]{4}{*}{ Type of tertiary degree (Pre-reform or single-tier) } & Master & & $-0.015^{* * *}$ \\
\hline & & & $(0.005)$ \\
\hline & Bachelor & & -0.004 \\
\hline & & & $(0.004)$ \\
\hline \multirow[t]{14}{*}{ Field of study (Humanities and Social Sciences) } & Mathematics, Physics, Chemistry & & $0.033 * * *$ \\
\hline & & & $(0.004)$ \\
\hline & ICT and Engineering & & $0.014 * * *$ \\
\hline & & & $(0.003)$ \\
\hline & Medicine and health professions & & $-0.019 * * *$ \\
\hline & & & $(0.003)$ \\
\hline & Architecture & & $0.011^{* *}$ \\
\hline & & & $(0.005)$ \\
\hline & Economics and Statistics & & -0.002 \\
\hline & & & $(0.003)$ \\
\hline & Foreign Languages & & $0.036 * * *$ \\
\hline & & & $(0.005)$ \\
\hline & Law & & $-0.022 * * *$ \\
\hline & & & $(0.003)$ \\
\hline \multirow[t]{5}{*}{ Tertiary graduation mark (66-90) } & $91-100$ & & 0.001 \\
\hline & & & $(0.004)$ \\
\hline & $101-105$ & & 0.007 \\
\hline & & & $(0.004)$ \\
\hline & $106-110$ & & 0.004 \\
\hline
\end{tabular}




\begin{tabular}{|c|c|c|c|}
\hline & & Mod. 1 & Mod. 2 \\
\hline & & & $(0.004)$ \\
\hline & 110 cum laude & & $0.021 * * *$ \\
\hline & & & $(0.005)$ \\
\hline \multirow[t]{6}{*}{ Location of the university (North-West) } & North-East & & $-0.006 * *$ \\
\hline & & & $(0.003)$ \\
\hline & Centre & & $-0.010 * * *$ \\
\hline & & & $(0.003)$ \\
\hline & South & & $-0.023 * * *$ \\
\hline & & & $(0.003)$ \\
\hline \multirow[t]{2}{*}{ Experience abroad, e.g. Erasmus (No) } & Yes & & $0.057 * * *$ \\
\hline & & & $(0.002)$ \\
\hline \multirow{2}{*}{ Type of university (Public) } & Private & & 0.001 \\
\hline & & & $(0.003)$ \\
\hline Number of observations & & 47,534 & 47,534 \\
\hline Pseudo R2 & & 0.097 & 0.202 \\
\hline
\end{tabular}

Source: own elaboration on ISTAT data (2015)

Standard errors in parentheses

$* * * p<0.01, * * p<0.05, * p<0.1$

Table 4 Employment condition of graduates. Multinomial logistic regression models, average marginal effects. 2015

\begin{tabular}{|c|c|c|c|c|}
\hline & & Student & Unemployed & Employed \\
\hline \multirow[t]{6}{*}{ Current residence (Italy) } & Northern Europe & $\begin{array}{c}0.075^{* * *} \\
(0.014)\end{array}$ & $\begin{array}{l}-0.016 \\
(0.010)\end{array}$ & $\begin{array}{c}-0.038^{* *} \\
(0.017)\end{array}$ \\
\hline & Western Continental Europe & $\begin{array}{c}0.115^{* * *} \\
(0.013)\end{array}$ & $\begin{array}{l}-0.014 \\
(0.009)\end{array}$ & $\begin{array}{c}-0.095 * * * \\
(0.015)\end{array}$ \\
\hline & Southern Europe & $\begin{array}{c}0.098 * * * \\
(0.029)\end{array}$ & $\begin{array}{l}-0.002 \\
(0.019)\end{array}$ & $\begin{array}{c}-0.114^{* * *} \\
(0.034)\end{array}$ \\
\hline & Eastern Europe & $\begin{array}{c}-0.063^{* *} \\
(0.026)\end{array}$ & $\begin{array}{l}-0.011 \\
(0.027)\end{array}$ & $\begin{array}{c}0.046 \\
(0.044)\end{array}$ \\
\hline & Developed extra-EU countries & $\begin{array}{c}0.068 * * * \\
(0.024)\end{array}$ & $\begin{array}{l}-0.010 \\
(0.018)\end{array}$ & $\begin{array}{c}-0.110^{* * *} \\
(0.032)\end{array}$ \\
\hline & Developing extra-EU countries & $\begin{array}{l}-0.017 \\
(0.022)\end{array}$ & $\begin{array}{c}0.021 \\
(0.017)\end{array}$ & $\begin{array}{c}0.000 \\
(0.031)\end{array}$ \\
\hline Observations & & & 47,534 & \\
\hline Pseudo R2 & & & 0,095 & \\
\hline
\end{tabular}

Source: own elaboration on Istat data (2015)

Standard errors in parentheses

$* * * p<0.01, * * p<0.05, * p<0.1$

Table 5 Returns to migration. Standard regression and propensity score matching estimate. 2015

\begin{tabular}{|c|c|c|c|}
\hline & & Standard regression & $\begin{array}{c}\text { Propensity score matching } \\
\text { (ATT estimates) }\end{array}$ \\
\hline \multirow[t]{2}{*}{ Earnings $^{\mathrm{a}}$} & Coef & $0.368 * * *$ & $0.362^{* * *}$ \\
\hline & SE & $(0.020)$ & $(0.020)$ \\
\hline \multirow[t]{2}{*}{ Subjective overeducation ${ }^{a}$} & Coef & 0.012 & $0.051^{* * *}$ \\
\hline & SE & $(0.012)$ & $(0.015)$ \\
\hline \multirow[t]{2}{*}{ Skilled Employment ${ }^{\mathrm{a}}$} & Coef & $0.055^{* * *}$ & $0.068 * * *$ \\
\hline & SE & $(0.012)$ & $(0.015)$ \\
\hline \multirow[t]{2}{*}{ Career prospects ${ }^{a}$} & Coef & $0.192 * * *$ & $0.204^{* * *}$ \\
\hline & SE & $(0.012)$ & $(0.014)$ \\
\hline
\end{tabular}

Source: own elaboration on ISTAT data (2015)

$* * * p<0.01, * * p<0.05, * p<0.1$

Note: ${ }^{a} 5$ observations off support in the propensity score estimates 


\section{Appendix}

Table A1 Employment condition of graduates. Multinomial logistic regression models, average marginal effects. Full results. 2015

\begin{tabular}{|c|c|c|c|c|}
\hline & & Student & Unemployed & Employed \\
\hline \multirow[t]{6}{*}{ Current residence (Italy) } & Northern Europe & $\begin{array}{c}0.075^{* * *} \\
(0.014)\end{array}$ & $\begin{array}{l}-0.016 \\
(0.010)\end{array}$ & $\begin{array}{c}-0.038^{* *} \\
(0.017)\end{array}$ \\
\hline & Western Continental Europe & $\begin{array}{c}0.115^{* * *} \\
(0.013)\end{array}$ & $\begin{array}{l}-0.014 \\
(0.009)\end{array}$ & $\begin{array}{c}-0.095^{* * *} \\
(0.015)\end{array}$ \\
\hline & Southern Europe & $\begin{array}{c}0.098 * * * \\
(0.029)\end{array}$ & $\begin{array}{l}-0.002 \\
(0.019)\end{array}$ & $\begin{array}{c}-0.114^{* * *} \\
(0.034)\end{array}$ \\
\hline & Eastern Europe & $\begin{array}{c}-0.063 * * \\
(0.026)\end{array}$ & $\begin{array}{l}-0.011 \\
(0.027)\end{array}$ & $\begin{array}{c}0.046 \\
(0.044)\end{array}$ \\
\hline & Developed extra-EU countries & $\begin{array}{c}0.068 * * * \\
(0.024)\end{array}$ & $\begin{array}{l}-0.010 \\
(0.018)\end{array}$ & $\begin{array}{c}-0.110^{* * *} \\
(0.032)\end{array}$ \\
\hline & Developing extra-EUcountries & $\begin{array}{l}-0.017 \\
(0.022)\end{array}$ & $\begin{array}{l}-0.021 \\
(0.017)\end{array}$ & $\begin{array}{c}0.000 \\
(0.031)\end{array}$ \\
\hline Sex (Male) & Female & $\begin{array}{c}-0.011 * * * \\
(0.003)\end{array}$ & $\begin{array}{c}0.021^{* * *} \\
(0.003)\end{array}$ & $\begin{array}{c}-0.031^{* * *} \\
(0.004)\end{array}$ \\
\hline \multirow[t]{2}{*}{ Age (Less than 25) } & $25-29$ & $\begin{array}{l}-0.002 \\
(0.005)\end{array}$ & $\begin{array}{l}-0.001 \\
(0.004)\end{array}$ & $\begin{array}{c}0.004 \\
(0.006)\end{array}$ \\
\hline & $30+$ & $\begin{array}{c}-0.115^{* * *} \\
(0.005)\end{array}$ & $\begin{array}{c}-0.026 * * * \\
(0.004)\end{array}$ & $\begin{array}{c}0.140^{* * *} \\
(0.007)\end{array}$ \\
\hline \multirow[t]{5}{*}{ Parents' occupational class (Manager) } & Entrepreneur & $\begin{array}{c}-0.045^{* * *} \\
(0.013)\end{array}$ & $\begin{array}{c}-0.017^{*} \\
(0.010)\end{array}$ & $\begin{array}{c}0.038^{* *} \\
(0.017)\end{array}$ \\
\hline & Clerk & $\begin{array}{c}-0.023^{* * *} \\
(0.004)\end{array}$ & $\begin{array}{l}0.005^{*} \\
(0.003)\end{array}$ & $\begin{array}{c}0.017^{* * *} \\
(0.005)\end{array}$ \\
\hline & Self-employed & $\begin{array}{c}-0.030 * * * \\
(0.008)\end{array}$ & $\begin{array}{c}0.001 \\
(0.006)\end{array}$ & $\begin{array}{c}0.024^{* *} \\
(0.010)\end{array}$ \\
\hline & Manual worker & $\begin{array}{c}-0.027^{* * *} \\
(0.005)\end{array}$ & $\begin{array}{c}0.018^{* * *} \\
(0.004)\end{array}$ & $\begin{array}{c}-0.002 \\
(0.006)\end{array}$ \\
\hline & Unemployed/Inactive & $\begin{array}{c}-0.019 * * * \\
(0.005)\end{array}$ & $\begin{array}{l}-0.004 \\
(0.004)\end{array}$ & $\begin{array}{c}0.009 \\
(0.006)\end{array}$ \\
\hline Citizenship (Italian) & Foreign & $\begin{array}{c}0.002 \\
(0.015)\end{array}$ & $\begin{array}{c}0.031 * * * \\
(0.011)\end{array}$ & $\begin{array}{c}-0.043^{* *} \\
(0.019)\end{array}$ \\
\hline \multirow[t]{2}{*}{ Residence before university (Region of Athenaeum) } & Other region & $\begin{array}{c}0.013 * * * \\
(0.004)\end{array}$ & $\begin{array}{c}0.009 * * * \\
(0.003)\end{array}$ & $\begin{array}{c}-0.023 * * * \\
(0.005)\end{array}$ \\
\hline & Abroad & $\begin{array}{c}0.018 \\
(0.015)\end{array}$ & $\begin{array}{c}0.018 \\
(0.016)\end{array}$ & $\begin{array}{c}-0.040^{*} \\
(0.022)\end{array}$ \\
\hline \multirow[t]{6}{*}{ Type of secondary degree (Scientific lyceum) } & Classical lyceum & $\begin{array}{c}-0.027^{* * *} \\
(0.005)\end{array}$ & $\begin{array}{c}-0.009^{* *} \\
(0.004)\end{array}$ & $\begin{array}{c}0.047^{* * *} \\
(0.006)\end{array}$ \\
\hline & Foreign-language lyceum & $\begin{array}{c}-0.063^{* * *} \\
(0.007)\end{array}$ & $\begin{array}{l}-0.005 \\
(0.006)\end{array}$ & $\begin{array}{c}0.080^{* * *} \\
(0.010)\end{array}$ \\
\hline & Other lyceum & $\begin{array}{c}-0.081 * * * \\
(0.006)\end{array}$ & $\begin{array}{l}-0.006 \\
(0.005)\end{array}$ & $\begin{array}{c}0.094 * * * \\
(0.008)\end{array}$ \\
\hline & Technical school & $\begin{array}{c}-0.066 * * * \\
(0.006)\end{array}$ & $\begin{array}{c}-0.010 * * \\
(0.004)\end{array}$ & $\begin{array}{c}0.087^{* * *} \\
(0.007)\end{array}$ \\
\hline & Vocational school & $\begin{array}{c}-0.090^{* * *} \\
(0.008)\end{array}$ & $\begin{array}{c}0.003 \\
(0.007)\end{array}$ & $\begin{array}{c}0.091 * * * \\
(0.010)\end{array}$ \\
\hline & Other school & $\begin{array}{c}-0.019 \\
(0.027)\end{array}$ & $\begin{array}{l}-0.007 \\
(0.020)\end{array}$ & $\begin{array}{c}0.013 \\
(0.034)\end{array}$ \\
\hline Upper secondary graduation mark & & $\begin{array}{c}0.002^{* * *} \\
(0.000)\end{array}$ & $\begin{array}{c}-0.001^{* * *} \\
(0.000)\end{array}$ & $\begin{array}{c}-0.001^{* * *} \\
(0.000)\end{array}$ \\
\hline Matriculation year & & $\begin{array}{c}-0.009 * * * \\
(0.001)\end{array}$ & $\begin{array}{c}-0.005 * * * \\
(0.001)\end{array}$ & $\begin{array}{c}0.019 * * * \\
(0.001)\end{array}$ \\
\hline \multirow[t]{2}{*}{ Type of tertiary degree (Pre-reform or single-tier) } & Master & $\begin{array}{c}-0.111 * * * \\
(0.008)\end{array}$ & $\begin{array}{c}0.040 * * * \\
(0.005)\end{array}$ & $\begin{array}{c}0.057^{* * *} \\
(0.010)\end{array}$ \\
\hline & Bachelor & $\begin{array}{c}-0.042 * * * \\
(0.007)\end{array}$ & $\begin{array}{c}0.011^{* * *} \\
(0.004)\end{array}$ & $\begin{array}{c}0.023 * * * \\
(0.008)\end{array}$ \\
\hline \multirow[t]{3}{*}{ Field of study (Humanities and Social Sciences) } & Mathematics, Physics, Chemistry & $\begin{array}{c}0.102^{* * *} \\
(0.006)\end{array}$ & $\begin{array}{c}0.006 \\
(0.005)\end{array}$ & $\begin{array}{c}-0.100 * * * \\
(0.008)\end{array}$ \\
\hline & $\mathrm{ICT}$ and Engineering & $\begin{array}{c}0.012^{* *} \\
(0.005)\end{array}$ & $\begin{array}{c}-0.034 * * * \\
(0.004)\end{array}$ & $\begin{array}{c}0.053^{* * *} \\
(0.007)\end{array}$ \\
\hline & Medicine and health professions & $0.035 * * *$ & $-0.030 * * *$ & $0.018^{* * *}$ \\
\hline
\end{tabular}




\begin{tabular}{|c|c|c|c|c|}
\hline & & Student & Unemployed & Employed \\
\hline & & $(0.005)$ & $(0.004)$ & $(0.007)$ \\
\hline & Architecture & $-0.078 * * *$ & -0.003 & $0.086 * * *$ \\
\hline & & $(0.005)$ & $(0.007)$ & $(0.010)$ \\
\hline & Economics and Statistics & $-0.017^{* * *}$ & $-0.010 * *$ & $0.045^{* * *}$ \\
\hline & & $(0.006)$ & $(0.004)$ & $(0.007)$ \\
\hline & Foreign Languages & $-0.016 * *$ & 0.009 & 0.004 \\
\hline & & $(0.007)$ & $(0.007)$ & $(0.010)$ \\
\hline & Law & $-0.037 * * *$ & $0.040 * * *$ & $-0.029 * * *$ \\
\hline & & $(0.005)$ & $(0.006)$ & $(0.008)$ \\
\hline \multirow[t]{8}{*}{ Tertiary graduation mark (66-90) } & $91-100$ & -0.008 & -0.004 & $0.014^{*}$ \\
\hline & & $(0.006)$ & $(0.005)$ & $(0.008)$ \\
\hline & 101-105 & -0.005 & -0.007 & $0.016^{*}$ \\
\hline & & $(0.006)$ & $(0.006)$ & (0.009) \\
\hline & $106-110$ & $0.017^{* * *}$ & $-0.014 * *$ & -0.002 \\
\hline & & $(0.007)$ & $(0.006)$ & $(0.009)$ \\
\hline & 110 cum laude & $0.054 * * *$ & $-0.016 * * *$ & $-0.031 * * *$ \\
\hline & & $(0.007)$ & $(0.006)$ & (0.009) \\
\hline \multirow[t]{6}{*}{ Location of the athenaeum (North-West) } & North-East & $0.017^{* * *}$ & $0.007 * *$ & $-0.031 * * *$ \\
\hline & & $(0.004)$ & $(0.003)$ & $(0.005)$ \\
\hline & Centre & $0.027^{* * *}$ & $0.031 * * *$ & $-0.075 * * *$ \\
\hline & & $(0.004)$ & $(0.003)$ & $(0.006)$ \\
\hline & South & $0.048 * * *$ & $0.072 * * *$ & $-0.158 * * *$ \\
\hline & & $(0.004)$ & $(0.004)$ & $(0.005)$ \\
\hline \multirow[t]{2}{*}{ Experience abroad, e.g. Erasmus (No) } & Yes & $0.023^{* * *}$ & $-0.014^{* * *}$ & 0.002 \\
\hline & & $(0.005)$ & $(0.005)$ & $(0.007)$ \\
\hline \multirow[t]{2}{*}{ Type of university (public) } & Private & -0.006 & $-0.010 * *$ & 0.012 \\
\hline & & $(0.006)$ & $(0.005)$ & $(0.008)$ \\
\hline Observations & & 47,534 & 47,534 & 47,534 \\
\hline Pseudo R2 & & & 0.095 & \\
\hline
\end{tabular}

Source: own elaboration on ISTAT data (2015)

Standard errors in parentheses

$* * * p<0.01, * * p<0.05, * p<0.1$ 
Table A2 Returns to migration, full results. 2015

\begin{tabular}{|c|c|c|c|c|c|}
\hline & & Earnings $^{a}$ & Overeducation $^{\mathbf{b}}$ & Skilled Employment ${ }^{\mathrm{b}}$ & Satisfaction $^{\mathbf{b}}$ \\
\hline \multirow[t]{12}{*}{ Current residence (Italy) } & Northern Europe & $0.277^{* * *}$ & $0.044 * *$ & 0.023 & $0.302 * * *$ \\
\hline & & $(0.034)$ & $(0.021)$ & $(0.020)$ & $(0.024)$ \\
\hline & Western Continental Europe & $0.357^{* * *}$ & -0.014 & $0.055^{* * *}$ & $0.175^{* * *}$ \\
\hline & & $(0.030)$ & $(0.018)$ & $(0.018)$ & $(0.021)$ \\
\hline & Southern Europe & $0.161^{* *}$ & $0.096 * *$ & 0.032 & 0.065 \\
\hline & & $(0.069)$ & $(0.045)$ & $(0.041)$ & $(0.047)$ \\
\hline & Eastern Europe & $0.401 * * *$ & 0.019 & 0.067 & $0.139 * *$ \\
\hline & & $(0.087)$ & $(0.053)$ & $(0.050)$ & $(0.060)$ \\
\hline & Developed extra-EU countries & $0.429 * * *$ & 0.043 & $0.118 * * *$ & $0.179 * * *$ \\
\hline & & $(0.062)$ & $(0.039)$ & $(0.038)$ & $(0.044)$ \\
\hline & Developing extra-EUcountries & $0.759 * * *$ & $-0.068 * *$ & $0.115^{* * *}$ & $0.301 * * *$ \\
\hline & & $(0.058)$ & $(0.031)$ & $(0.035)$ & $(0.040)$ \\
\hline \multirow[t]{2}{*}{ Sex (Male) } & Female & -0.009 & $-0.016 * * *$ & $-0.021 * * *$ & $-0.043 * * *$ \\
\hline & & $(0.008)$ & $(0.006)$ & $(0.005)$ & $(0.005)$ \\
\hline \multirow[t]{4}{*}{ Age (Less than 25) } & $25-29$ & -0.010 & 0.003 & $0.052 * * *$ & $-0.041 * * *$ \\
\hline & & $(0.011)$ & $(0.007)$ & $(0.007)$ & $(0.007)$ \\
\hline & $30+$ & $0.162 * * *$ & 0.015 & $0.076 * * *$ & $-0.087 * * *$ \\
\hline & & $(0.015)$ & $(0.012)$ & $(0.010)$ & $(0.010)$ \\
\hline \multirow[t]{10}{*}{ Parents' occupational class (Manager) } & Entrepreneur & -0.036 & $0.056 * *$ & -0.017 & $0.082 * * *$ \\
\hline & & $(0.034)$ & $(0.025)$ & $(0.021)$ & $(0.023)$ \\
\hline & Clerk & 0.007 & $0.013 * *$ & $-0.049 * * *$ & 0.004 \\
\hline & & $(0.009)$ & $(0.006)$ & $(0.006)$ & $(0.006)$ \\
\hline & Self-employed & $-0.045 * *$ & $0.027 * *$ & -0.019 & $0.023^{*}$ \\
\hline & & $(0.019)$ & $(0.014)$ & $(0.012)$ & $(0.013)$ \\
\hline & Manual worker & -0.007 & $0.018 * *$ & $-0.050 * * *$ & $-0.025 * * *$ \\
\hline & & $(0.012)$ & $(0.008)$ & $(0.007)$ & $(0.008)$ \\
\hline & Unemployed/Inactive & $-0.033 * * *$ & $0.023 * * *$ & $-0.017 * *$ & $0.014^{*}$ \\
\hline & & $(0.012)$ & $(0.009)$ & $(0.008)$ & $(0.008)$ \\
\hline \multirow[t]{2}{*}{ Citizenship (Italian) } & Foreign & -0.014 & $-0.051 *$ & 0.013 & -0.001 \\
\hline & & $(0.037)$ & $(0.026)$ & $(0.023)$ & $(0.024)$ \\
\hline \multirow[t]{4}{*}{ Residence before university (Region of Athenaeum) } & Other region & 0.003 & 0.002 & -0.002 & $0.016 * * *$ \\
\hline & & $(0.009)$ & $(0.006)$ & $(0.005)$ & $(0.006)$ \\
\hline & Abroad & 0.022 & -0.005 & -0.009 & 0.000 \\
\hline & & $(0.044)$ & $(0.028)$ & $(0.026)$ & $(0.027)$ \\
\hline \multirow[t]{2}{*}{ Type of secondary degree (Scientific lyceum) } & Classical lyceum & $0.037 * * *$ & -0.008 & $-0.033 * * *$ & -0.003 \\
\hline & & $(0.012)$ & $(0.008)$ & $(0.007)$ & $(0.008)$ \\
\hline
\end{tabular}




\begin{tabular}{|c|c|c|c|c|c|}
\hline & & Earnings $^{\mathrm{a}}$ & Overeducation $^{\mathbf{b}}$ & Skilled Employment ${ }^{\mathrm{b}}$ & Satisfaction $^{\mathrm{b}}$ \\
\hline & Foreign-language lyceum & -0.011 & 0.020 & $-0.051 * * *$ & 0.004 \\
\hline & & $(0.019)$ & $(0.013)$ & $(0.012)$ & $(0.013)$ \\
\hline & Other lyceum & $0.082^{* * *}$ & $0.027 * *$ & 0.010 & -0.014 \\
\hline & & $(0.017)$ & $(0.012)$ & $(0.010)$ & $(0.011)$ \\
\hline & Technical school & $0.041 * * *$ & $0.036 * * *$ & $-0.083 * * *$ & -0.001 \\
\hline & & $(0.014)$ & $(0.009)$ & $(0.008)$ & $(0.009)$ \\
\hline & Vocational school & 0.030 & $0.028^{*}$ & $-0.111 * * *$ & 0.013 \\
\hline & & $(0.020)$ & $(0.015)$ & $(0.013)$ & $(0.013)$ \\
\hline & Other school & $-0.207 * * *$ & $0.098 * *$ & -0.044 & -0.019 \\
\hline & & $(0.064)$ & $(0.048)$ & $(0.040)$ & $(0.041)$ \\
\hline \multirow[t]{2}{*}{ Upper secondary graduation mark } & & $0.001^{* * *}$ & $-0.001 * * *$ & $0.002 * * *$ & 0.000 \\
\hline & & $(0.000)$ & $(0.000)$ & $(0.000)$ & $(0.000)$ \\
\hline \multirow[t]{2}{*}{ Matriculation year } & & $0.025^{* * *}$ & $-0.027 * * *$ & $0.022 * * *$ & $0.013 * * *$ \\
\hline & & $(0.002)$ & $(0.002)$ & $(0.001)$ & $(0.002)$ \\
\hline \multirow[t]{4}{*}{ Type of tertiary degree (Pre-reform or single-tier) } & Master & $-0.035^{*}$ & $0.198 * * *$ & $-0.352 * * *$ & $-0.098 * * *$ \\
\hline & & $(0.018)$ & $(0.009)$ & $(0.010)$ & $(0.013)$ \\
\hline & Bachelor & $-0.034 * *$ & $0.329 * * *$ & $-0.544 * * *$ & $-0.085 * * *$ \\
\hline & & $(0.016)$ & $(0.008)$ & $(0.009)$ & $(0.011)$ \\
\hline \multirow[t]{14}{*}{ Field of study (Humanities and Social Sciences) } & Mathematics, Physics, Chemistry & $0.083 * * *$ & $-0.165 * * *$ & $0.101 * * *$ & $0.030 * * *$ \\
\hline & & $(0.015)$ & $(0.011)$ & $(0.009)$ & $(0.009)$ \\
\hline & ICT and Engineering & $0.160 * * *$ & $-0.266 * * *$ & $0.226 * * *$ & $0.070 * * *$ \\
\hline & & $(0.014)$ & $(0.010)$ & $(0.008)$ & $(0.009)$ \\
\hline & Medicine and health professions & $0.167 * * *$ & $-0.420 * * *$ & $-0.164 * * *$ & -0.002 \\
\hline & & $(0.013)$ & $(0.007)$ & $(0.009)$ & $(0.008)$ \\
\hline & Architecture & $-0.248 * * *$ & $-0.081 * * *$ & $0.167 * * *$ & 0.014 \\
\hline & & $(0.021)$ & $(0.016)$ & $(0.014)$ & $(0.013)$ \\
\hline & Economics and Statistics & $0.064 * * *$ & $-0.107 * * *$ & $-0.048 * * *$ & $0.118^{* * *}$ \\
\hline & & $(0.013)$ & $(0.011)$ & $(0.008)$ & $(0.009)$ \\
\hline & Foreign Languages & $0.035^{*}$ & $0.047 * * *$ & $-0.048 * * *$ & -0.000 \\
\hline & & $(0.019)$ & $(0.015)$ & $(0.012)$ & $(0.012)$ \\
\hline & Law & $-0.333 * * *$ & $-0.131 * * *$ & 0.002 & $0.064 * * *$ \\
\hline & & $(0.016)$ & $(0.013)$ & $(0.010)$ & $(0.010)$ \\
\hline \multirow[t]{5}{*}{ Tertiary graduation mark (66-90) } & $91-100$ & $-0.035 * *$ & -0.002 & -0.005 & $-0.018 *$ \\
\hline & & $(0.015)$ & $(0.011)$ & $(0.010)$ & $(0.010)$ \\
\hline & $101-105$ & $-0.036 * *$ & -0.014 & 0.010 & $-0.031 * * *$ \\
\hline & & $(0.016)$ & $(0.012)$ & $(0.011)$ & $(0.011)$ \\
\hline & $106-110$ & -0.020 & $-0.039 * * *$ & 0.017 & $-0.030 * * *$ \\
\hline
\end{tabular}




\begin{tabular}{|c|c|c|c|c|c|}
\hline & & Earnings $^{\mathrm{a}}$ & Overeducation $^{\text {b }}$ & Skilled Employment ${ }^{\mathrm{b}}$ & Satisfaction $^{\mathrm{b}}$ \\
\hline & & $(0.017)$ & $(0.012)$ & $(0.011)$ & $(0.011)$ \\
\hline & 110 cum laude & -0.022 & $-0.057 * * *$ & $0.053 * * *$ & $-0.048 * * *$ \\
\hline & & $(0.018)$ & $(0.013)$ & $(0.011)$ & $(0.012)$ \\
\hline \multirow[t]{6}{*}{ Location of the athenaeum (North-West) } & North-East & $-0.023 * *$ & $0.041 * * *$ & $-0.013^{*}$ & 0.001 \\
\hline & & $(0.011)$ & $(0.007)$ & $(0.007)$ & $(0.007)$ \\
\hline & Centre & $-0.064^{* * *}$ & $0.038 * * *$ & -0.002 & 0.005 \\
\hline & & $(0.011)$ & $(0.008)$ & $(0.007)$ & $(0.007)$ \\
\hline & South & $-0.101^{* * *}$ & $0.020 * * *$ & -0.009 & $0.012^{*}$ \\
\hline & & $(0.011)$ & $(0.007)$ & $(0.007)$ & $(0.007)$ \\
\hline \multirow[t]{2}{*}{ Experience abroad, e.g. Erasmus (No) } & Yes & $0.034 * *$ & -0.002 & 0.007 & $0.016^{*}$ \\
\hline & & $(0.013)$ & $(0.008)$ & $(0.008)$ & $(0.008)$ \\
\hline \multirow[t]{2}{*}{ Current job started (Before graduation) } & After graduation & $-0.095^{* * *}$ & 0.000 & $0.037 * * *$ & $0.013^{*}$ \\
\hline & & $(0.011)$ & $(0.000)$ & $(0.006)$ & $(0.007)$ \\
\hline \multirow[t]{2}{*}{ Working hours (Full time) } & Part time & $0.037 * * *$ & & & \\
\hline & & $(0.010)$ & & & \\
\hline \multirow[t]{2}{*}{ Type of university (Public) } & Private & $0.057 * * *$ & $-0.033 * * *$ & $0.021 * * *$ & $0.022 * *$ \\
\hline & & $(0.014)$ & $(0.010)$ & $(0.008)$ & $(0.009)$ \\
\hline \multirow[t]{2}{*}{ Worked during studies (No) } & Yes & $0.067 * * *$ & -0.002 & $-0.012 * * *$ & 0.002 \\
\hline & & $(0.006)$ & $(0.004)$ & $(0.004)$ & $(0.004)$ \\
\hline \multirow[t]{2}{*}{ Constant } & & $-47.140 * * *$ & & & \\
\hline & & $(4.882)$ & & & \\
\hline Observations & & 32,981 & 26,466 & 35,055 & 35,055 \\
\hline R-squared (or Pseudo-R2) & & 0.086 & 0,1524 & 0,2189 & 0,0265 \\
\hline
\end{tabular}

Source: own elaboration on ISTAT data (2015)

Standard errors in parentheses

$* * * p<0.01, * * p<0.05, * p<0.1$

Note: aLinear regression; ${ }^{b}$ Logit regression, average marginal effects 